\title{
Arbuscular mycorrhizal fungi and biochar influence simazine decomposition and leaching
}

Cheng, Hongguang; Wang, Jinyang; Tu, Chenglong; Lin, Shan; Xing, Dan; Hill, Paul; Chadwick, Dave; Jones, Davey L.

\section{Global Change Biology Bioenergy}

DOI:

$10.1111 / g c b b .12802$

Published: 01/04/2021

Publisher's PDF, also known as Version of record

Cyswllt i'r cyhoeddiad / Link to publication

Dyfyniad o'r fersiwn a gyhoeddwyd / Citation for published version (APA):

Cheng, H., Wang, J., Tu, C., Lin, S., Xing, D., Hill, P., Chadwick, D., \& Jones, D. L. (2021).

Arbuscular mycorrhizal fungi and biochar influence simazine decomposition and leaching. Global Change Biology Bioenergy, 13(4), 708-718. https://doi.org/10.1111/gcbb.12802

\footnotetext{
Hawliau Cyffredinol / General rights

Copyright and moral rights for the publications made accessible in the public portal are retained by the authors and/or other copyright owners and it is a condition of accessing publications that users recognise and abide by the legal requirements associated with these rights. study or research.

- Users may download and print one copy of any publication from the public portal for the purpose of private

- You may not further distribute the material or use it for any profit-making activity or commercial gain

- You may freely distribute the URL identifying the publication in the public portal?
}

Take down policy

If you believe that this document breaches copyright please contact us providing details, and we will remove access to the work immediately and investigate your claim. 


\title{
Arbuscular mycorrhizal fungi and biochar influence simazine decomposition and leaching
}

\author{
Hongguang Cheng ${ }^{1,2}$ (1) | Jinyang Wang ${ }^{2}$ | Chenglong Tu ${ }^{3,4}$ | Shan Lin ${ }^{5}$ | Dan Xing ${ }^{6}$ | \\ Paul Hill $^{2}$ | Dave Chadwick ${ }^{2}$ | Davey L. Jones ${ }^{2,7}$
}

${ }^{1}$ State Key Laboratory of Environmental Geochemistry, Institute of Geochemistry, Chinese Academy of Sciences, Guiyang, Guizhou, China

${ }^{2}$ School of Natural Sciences, Bangor University, Bangor, UK

${ }^{3}$ Key Laboratory of Environmental Pollution Monitoring and Disease Control, Ministry of Education, Guizhou Medical University, Guiyang, China

${ }^{4}$ Toxicity Testing Center of Guizhou Medical University, Guiyang, China

${ }^{5}$ Key Laboratory of Arable Land Conservation (Middle and Lower Reaches of Yangtze River), College of Resources and Environment, Ministry of Agriculture, Huazhong Agricultural University, Wuhan, China

${ }^{6}$ Guizhou Academy of Agricultural Science, Institute of Pepper Guiyang, Guiyang, China

${ }^{7}$ UWA School of Agriculture and Environment, University of Western Australia, Perth, WA, Australia

\section{Correspondence}

Hongguang Cheng, State Key Laboratory of Environmental Geochemistry, Institute of Geochemistry, Chinese Academy of Sciences, Guiyang, Guizhou 550081,

China.

Email: chenghongguang@vip.gyig.ac.cn

\section{Funding information}

Strategic Priority Research Program of Chinese Academy of Sciences, Grant/Award Number: XDB40020402; National Key Research and Development Program of China, Grant/Award Number: 2018YFC1802601; National Natural Science Foundation of China, Grant/ Award Number: C200709; Science and Technology Plan Project of Guizhou Province, Grant/Award Number: [2018]2329; Opening Fund of the State Key Laboratory of Environmental Geochemistry, Grant/Award Number: SKLEG 2020205

\begin{abstract}
The application of biochar to land has been promoted as a strategy for sequestering carbon in soils, for improving soil fertility and remediating soil pollution. However, the implications of biochar amendments on mycorrhizal associations and pesticide decomposition in agricultural soils are poorly understood. In this study, we compared the effects of four treatments; control (no biochar and no arbuscular mycorrhizal fungi (AMF), biochar (biochar without AMF), AMF (AMF without biochar) and biochar + AMF (AMF and biochar) on the fate of simazine. We specifically focused on the sorption, leaching and biodegradation behaviour of simazine. Our results showed that when symbiosis existed between plants and AMF, biochar inhibited simazine decomposition and AMF inoculation alleviated this inhibition. In contrast, this alleviation was not observed when the plant was removed. In addition, AMF inoculated into the biochar amended soil significantly decreased simazine concentration in the leachate; however, in the AMF-only treatment, no effect on simazine leaching was observed. These phenomena were attributed to variation in the soil's sorption capacity due to biochar application or AMF inoculation. Overall, biochar application combined with AMF inoculation has the potential to mitigate simazine accumulation in the topsoil and reduce its availability.
\end{abstract}

\section{K E Y W O R D S}

adsorption, decomposition, leaching, simazine, symbiosis

[Correction added on 4 June 2021, after first online publication: Funding details have been reordered.]

This is an open access article under the terms of the Creative Commons Attribution License, which permits use, distribution and reproduction in any medium, provided the original 


\section{1 | INTRODUCTION}

Simazine (1-Chloro-3,5-bisethylamino-2,4,6-triazine) is a commonly used pesticide in agriculture and forestry for controlling broadleaf and grassy weeds. Because of its longer half-life (Jones et al., 2011; Wauchope et al., 1992), simazine can readily accumulate in soil where it is at risk of leaching and runoff (Jiang et al., 2011). For example, simazine is the second most commonly detected pesticide in surface water and groundwater in the United States, Europe and Australia, where it can be present at concentrations of up to several hundred micrograms per litre (Cox et al., 2000; Troiano et al., 2001). It therefore represents a risk to human and ecosystems health (Rico et al., 2012) via exposure to simazine through drinking water and the food chain, as well as direct uptake, and is known to induce some mutagenic or carcinogenic activity (Birnbaum \& Fenton, 2003; Bogdanffy et al., 2000; Hayes et al., 2006). Therefore, there is a need to adopt strategies to prevent accumulation of pesticides in soil and decrease pesticide losses via leaching to safeguard human and ecosystem health.

Biochar is a carbon rich by-product produced during the pyrolysis of organic residues (Lehmann \& Joseph, 2009) in an oxygen-depleted environment (Lehmann et al., 2011a). It is considered an emerging technology for carbon sequestration, mitigation of climate change, soil improvement, crop productivity enhancement and environmental remediation (Atkinson et al., 2010; Ippolito et al., 2012; Lehmann \& Joseph, 2009; Maraseni, 2010; Spokas et al., 2012). Once incorporated into soil, biochar has been shown to alter soil properties (Kuppusamy et al., 2016), improve nutrient retention (Camps Arbestain et al., 2014), decrease greenhouse emissions (Chang et al., 2016) and increase sorption of contaminants (Cheng et al., 2017; Williams et al., 2015). It is well known that biochar application can increase the sorption of simazine in soil, thus decreasing its risk of leaching and direct uptake by plants. The high surface area and stronger cation exchange capacity of soil amended with biochar results in this greater adsorption of pesticides (Eibisch et al., 2015; Yu et al., 2010, 2011), resulting in lower concentration of pesticides in leachate (Larsbo et al., 2013; Tatarková et al., 2013) and low residues in the crop (Yang et al., 2010).

Although these benefits of biochar have been confirmed in recent studies, there are several potential negative implications, hazards and even risks to soil and water quality that other researchers have highlighted (Graber et al., 2012; Kookana, 2010; Kookana et al., 2011; Kuppusamy et al., 2016). For example, some studies have reported that biochar inhibits simazine biodegradation (Cheng et al., 2017; Jones et al., 2011) and reduces simazine efficacy for controlling weeds or killing pests (Graber et al., 2012; Kookana, 2010; Kuppusamy et al., 2016; Nag et al., 2011; Safaei Khorram et al., 2018; Yang et al., 2006). If biochar results in a longer half-life of pesticides in the soil, then greater concentrations will accumulate in the topsoil where it is at risk of losses to water via leaching and overland flow. With growing interest in the use of modified biochar with greater sorption capacity for remediating heavy metal and organic contamination of soil (Mandal et al., 2017; Trakal et al., 2016), pesticide decomposition could be reduced further resulting in increased risk of pesticide accumulation in the soil. These potential negative implications associated with biochar addition are not yet fully understood (Graber et al., 2012; Kookana, 2010; Nag et al., 2011)

Arbuscular mycorrhizal fungi (AMF) are ubiquitous soil organisms, forming symbiotic associations with the roots of c. $80 \%$ of all plants species (Bender et al., 2014). The hyphal network of AMF scavenge nutrients from soils and transfer a proportion to their host plant in return for labile plant carbon (Smith \& Read, 2008). Even though AMF have no known saprotrophic capability and cannot directly break down organic nutrients (Herman et al., 2012; Smith \& Read, 2008), past studies have reported that AMF can enhance decomposition of organic matter (OM; Hodge et al., 2001; Koller et al., 2013). For example, Cheng et al. (2012) showed that plant litter decomposed faster in the presence of AMF, especially under conditions of elevated $\mathrm{CO}_{2}$ and nitrogen $(\mathrm{N})$ concentrations. Likewise, Gui et al. (2017) measured increased OM decomposition while inhibiting soil microbial community development, in the presence of AMF, and hypothesized that AMF promoted OM decomposition by influencing the soil decomposer community. These studies highlighted the potential role of AMF in OM decomposition.

From this knowledge of the effects of biochar and AMF on the fate of pesticides in soil, we can hypothesize that combined amendment of biochar and AMF will positively affect simazine decomposition, adsorption and leaching. Therefore, in this study, we hypothesized that (a) higher simazine decomposition would occur when AMF was inoculated into soil amended with biochar because AMF would accelerate the decomposition of OM and (b) the sorption capacity of soil would increase when AMF was inoculated into the soil. The main aims of this study were to (1) observe the fate of simazine, including decomposition, adsorption and leaching in the soil amended with biochar; (2) investigate the fate of simazine in soil with AMF inoculation and (3) evaluate the influence of AMF inoculation combined with biochar application on the fate of simazine in soil.

\section{2 | MATERIALS AND METHODS}

\section{1 | Biochar, soil and AMF}

Biochar was produced from wheat (Triticum aestivum L.) straw, which was collected from the Henfaes Research 
Centre Wales, North Wales, UK $\left(53^{\circ} 140 \mathrm{~N} ; 4^{\circ} 100 \mathrm{~W}\right)$. The wheat straw was oven-dried $\left(80^{\circ} \mathrm{C}, 24 \mathrm{~h}\right)$ and then cut into $10 \mathrm{~cm}$ pieces before being placement into a glass pyrolysis vessel. The vessel was then placed in a muffle furnace for pyrolysis. The heating rate was $20^{\circ} \mathrm{C} \mathrm{min}^{-1}$, and the thermal treatment time was $0.5 \mathrm{~h}$ with peak pyrolysis temperatures $550^{\circ} \mathrm{C}$. The properties of biochar are shown in Table 1.

Soil was collected from the Ah horizon (0-15 cm, sandy loam) of a freely draining, grassland soil (Eutric Cambsiol soil type), which receives regular fertilization $\left(120 \mathrm{~kg} \mathrm{ha}^{-1} \mathrm{~N}\right.$, $60 \mathrm{~kg} \mathrm{ha}^{-1} \mathrm{~K}$ and $10 \mathrm{~kg} \mathrm{ha}^{-1} \mathrm{P}$ annually) and is located at the Henfaes Research Centre. The site is used for both grassland and arable production and has a mean annual temperature of $11^{\circ} \mathrm{C}$ (range $-5^{\circ} \mathrm{C}$ to $25^{\circ} \mathrm{C}$ ) and mean annual rainfall of $1060 \mathrm{~mm}$ (temperate climate regime). The soil was sieved to pass $2 \mathrm{~mm}$ to remove plant residues and stones and then air-dried at $20^{\circ} \mathrm{C}$ for 1 week prior to use. Subsequently, the soil was autoclaved $\left(121^{\circ} \mathrm{C}, 1 \mathrm{~h}\right)$ to remove and $\mathrm{AMF}$ in the soil. After autoclaving, soil was placed in a greenhouse for 1 month to allow the microbial community to recover. The major properties of the soil are shown in Table 1, with additional properties shown in Jones et al. $(2011,2012)$ and Farrar et al. (2012).

The mycorrhizal and rhizobial symbiotic inoculants were obtained from a commercial supplier (Plantworks Ltd). We choose an AMF which associates widely with cereals, namely Funneliformis mosseae (formerly Glomus mosseae) and which is known to be present at the site where the soil was collected. The inoculum consisted of

TA B LE 1 The properties of soil and biochar (data expressed on a dry weight basis)

\begin{tabular}{|c|c|c|}
\hline & Soil & Biochar \\
\hline $\mathrm{pH}$ & $5.94 \pm 0.15$ & $9.70 \pm 0.10$ \\
\hline $\begin{array}{l}\text { Electrical conductivity } \\
\qquad\left(\mu \mathrm{S} \mathrm{cm}^{-1}\right)\end{array}$ & $87.73 \pm 4.18$ & $4560 \pm 290$ \\
\hline $\begin{array}{l}\text { Water holding capacity } \\
\qquad(\%)\end{array}$ & $74.97 \pm 1.00$ & $659.77 \pm 9.14$ \\
\hline Total carbon (\%) & $3.10 \pm 0.05$ & $71.60 \pm 0.25$ \\
\hline Total nitrogen (\%) & $0.34 \pm 0.01$ & $1.18 \pm 0.02$ \\
\hline $\begin{array}{l}\text { Dissolved organic carbon } \\
\qquad\left(\mathrm{g} \mathrm{kg}^{-1}\right)\end{array}$ & $15.25 \pm 0.64$ & $14.27 \pm 1.27$ \\
\hline $\begin{array}{l}\text { Dissolved nitrogen } \\
\qquad\left(\mathrm{g} \mathrm{kg}^{-1}\right)\end{array}$ & $4.63 \pm 0.19$ & $0.17 \pm 0.03$ \\
\hline $\begin{array}{l}\text { Available } \\
\qquad \mathrm{NO}_{3}^{-}\left(\mathrm{mg} \mathrm{kg}^{-1}\right)\end{array}$ & $13.63 \pm 0.58$ & $0.00 \pm 0.00$ \\
\hline $\begin{array}{l}\text { Available } \mathrm{NH}_{4}^{+} \\
\qquad\left(\mathrm{mg} \mathrm{kg}^{-1}\right)\end{array}$ & $1.39 \pm 0.05$ & $2.38 \pm 0.14$ \\
\hline Available P $\left(\mathrm{mg} \mathrm{kg}^{-1}\right)$ & $0.60 \pm 0.04$ & $206.61 \pm 27.17$ \\
\hline
\end{tabular}

Note: All values represent means $\pm \operatorname{SEM}(n=3)$. a mixture of substrate, hyphae, spores and infected root fragments.

\subsection{Experimental design}

Four treatments were used in the experiment: (i) control (soil only, with no biochar or AMF inoculation); (ii) soil amended with biochar (dry soil-to-dry biochar ratio of $20: 1 \mathrm{w} / \mathrm{w}$ ); (iii) soil inoculated with AMF; and (iv) soil amended with biochar inoculated with AMF. To create the amended soils, replicate batches of biochar ( $300 \mathrm{~g}$, ground and sieved to pass $2 \mathrm{~mm}$ ) were added to replicate batches $(6 \mathrm{~kg})$ of air-dry soil and manually mixed to ensure homogeneity. For the treatment inoculated with AMF, $3 \mathrm{~g}$ of commercial mycorrhizal inoculum was mixed with either the soil alone (treatment ii), or the biochar-amended soil (treatment iv). To account for the effects of the AMF carrier, $3 \mathrm{~g}$ of substrate containing no AMF was added to the no AMF treatments. All the soil treatments were conducted in triplicate.

\section{3 $\mid$ Simazine decomposition}

To distinguish between the influence of AMF symbiosis and the presence of the host plant on the simazine decomposition, we divided our experiments into two parts, namely a pot experiment and a laboratory incubation experiment.

The pot experiment was performed in the isotope labelling facility at Environment Centre Wales, Bangor University. The mesocosms consisted of a cylindrical mesocosms (Figure 1) containing $1 \mathrm{~kg}$ of soil into which two pre-germinated maize

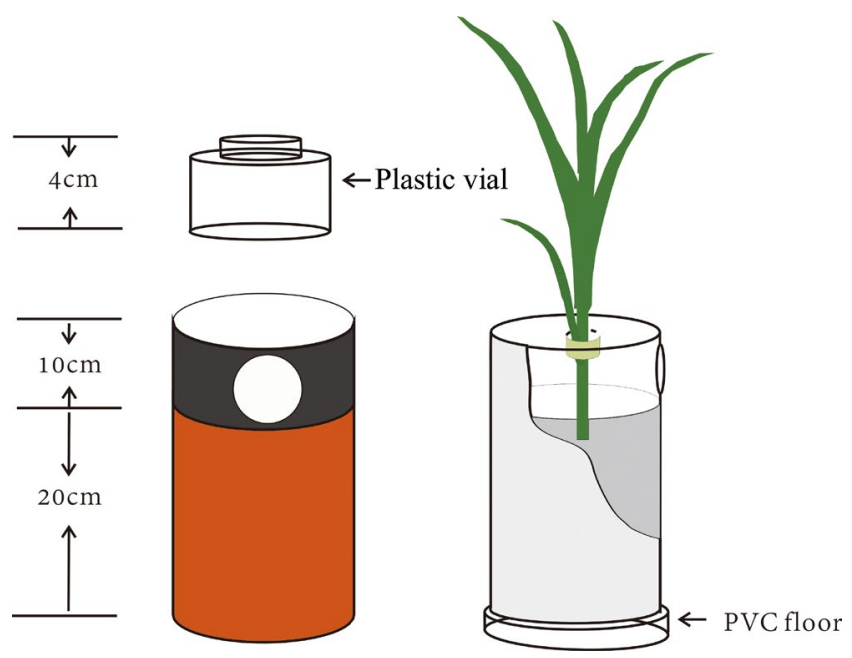

F I G URE 1 Pot equipment for exploring the effect of arbuscular mycorrhizal fungi symbiosis in biochar-amended soil on simazine decomposition 
(Zea mays L.) seeds were placed. The mesocosms were watered regularly to maintain field capacity. After 2 weeks, the maize seedlings were thinned to one plant and a plastic vial with a hole cut in the bottom placed around the stem of the maize seedling. At the same time, $30 \mathrm{ml}$ of Hoagland's modified basal salt mixture was added into each mesocosm to promote plant growth (Hoagland \& Arnon, 1950). In the sixth week, the stem was sealed into the top of the vial using one-component room-temperature-vulcanizing silicone (Figure 1). The surface of the soil column was then enclosed in transparent polypropylene which was sealed with tape to the vial. Subsequently, $60 \mathrm{ml}$ of ${ }^{14} \mathrm{C}$-ring-uniformly labelled simazine (6-chloro-N, $\mathrm{N}^{\prime}$-diethyl-1,3,5-triazine-2,4-diamine; $5 \mathrm{mCi} \mathrm{mmol}^{-1}$; Sigma Chemical Co.) in distilled water was added to the soil at a rate of $5 \mathrm{mg} \mathrm{kg}^{-1}$ (final simazine concentration, $8.34 \mathrm{mg} \mathrm{L}^{-1}$; $0.10 \mathrm{kBq} \mathrm{ml}^{-1}$ ). A $2 \mathrm{M} \mathrm{NaOH}$ trap ( $2 \mathrm{ml}$ ) was then placed inside the mesocosm to capture any ${ }^{14} \mathrm{CO}_{2}$ evolved and the mesocosms hermetically sealed and placed in a climate-controlled greenhouse at $25^{\circ} \mathrm{C}$. The $\mathrm{NaOH}$ traps were replaced after $1,3,6,9,12,15,18$ and 21 days. The ${ }^{14} \mathrm{CO}_{2}$ capture efficiency of the $\mathrm{NaOH}$ traps was $>98 \%$ (Jones et al., 2012). The ${ }^{14} \mathrm{CO}_{2}$ content in the $\mathrm{NaOH}$ traps was determined by liquid scintillation counting using Optiphase 3 scintillation fluid (PerkinElmer Corp.) and a Wallac 1404 liquid scintillation counter (PerkinElmer Corp.). Three weeks after labelling, the maize plant was harvested to determine dry weight and the plant and soil retained to determine their ${ }^{14} \mathrm{C}$ content.

An identical experiment to that described above was also established. In this experiment, however, immediately after the application of unlabelled simazine, the plants in the mesocosms were removed and soil was collected for biodedgradation and sorption experiments. Soil from each treatment (5 g) was weighed into $50 \mathrm{ml}$ polypropylene tube and adjusted to $60 \%$ of the water holding capacity (WHC). Subsequently, $0.5 \mathrm{ml}$ of ${ }^{14} \mathrm{C}$-labelled simazine $\left(1.0 \mathrm{mg} \mathrm{ml}^{-1}\right.$ and $\left.1.08 \mathrm{kBq} \mathrm{ml}^{-1}\right)$ was added to each sample. A $1 \mathrm{ml} \mathrm{NaOH}$ trap (1 M) was placed above the soil to capture $\mathrm{CO}_{2}$ released from the soil. The $\mathrm{NaOH}$ traps were replaced after $1,3,6,9,12,15,18$ and 21 days. The ${ }^{14} \mathrm{CO}_{2}$ content of the $\mathrm{NaOH}$ was measured as described above.

\subsection{Simazine adsorption}

Soil from each treatment was placed in individual $50 \mathrm{ml}$ polypropylene tubes. The tubes were then heat sterilized $\left(80^{\circ} \mathrm{C}, 30 \mathrm{~min}\right.$ ) to minimize microbial activity (Kuzyakov \& Jones, 2006). A ${ }^{14} \mathrm{C}$-labelled simazine solution in a background electrolyte of $0.01 \mathrm{M} \mathrm{CaCl}_{2}(20 \mathrm{ml})$ was then applied to the soil (total activity $0.1 \mathrm{kBq}$ ). A total of six concentrations of ${ }^{14} \mathrm{C}$ simazine were used, including 0 , $6.25,12.5,25,50$ and $100 \mu \mathrm{g} \mathrm{L}^{-1}$. The soil suspensions were shaken (200 rev $\min ^{-1}, 24 \mathrm{~h}$ ), which represented quasi-equilibrium conditions (Kookana et al., 1993). Subsequently, an aliquot $(1.0 \mathrm{ml})$ of the soil suspension was centrifuged $(10,000 \mathrm{~g} ; 5 \mathrm{~min})$ and the ${ }^{14} \mathrm{C}$ activity in the supernatant determined by liquid scintillation counting as described above. The partition coefficient $\left(K_{\mathrm{d}}\right)$ of simazine between the soil and the solution phase was calculated as follows:

$$
K_{\mathrm{d}}=C_{\mathrm{ads}} / C_{\mathrm{sol}} \text {, }
$$

where $C_{\text {ads }}\left(\mu \mathrm{g} \mathrm{g}^{-1}\right)$ is the concentration sorbed to the soil solid phase at equilibrium and $C_{\text {sol }}\left(\mathrm{mg} \mathrm{L}^{-1}\right)$ is the equilibrium solution concentration.

\section{5 $\quad$ Simazine leaching}

The effect of biochar and AMF on simazine leaching was determined according to the method of Jones et al. (2011) and Cheng et al. (2017). Briefly, approximately $5.0 \mathrm{~g}$ from each replicate treatment was placed into the barrel of individual $25 \mathrm{ml}$ syringe (20 $\mathrm{mm}$ diameter). A $1 \mathrm{~mm}$ polypropylene mesh was placed at the base of the column to prevent soil loss. Subsequently, distilled water was added to each column to saturate the soil. ${ }^{14} \mathrm{C}$-labelled simazine $(1 \mathrm{ml}$, $2.5 \mathrm{mg} \mathrm{L}^{-1}$ and $0.05 \mathrm{kBq} \mathrm{ml}^{-1}$ ) was then added to the soil surface and the sample left to equilibrate at $20^{\circ} \mathrm{C}$ for $1 \mathrm{~h}$. Before the start of leaching, another $1 \mathrm{~mm}$ polypropylene mesh was placed onto the soil surface to minimize droplet impact on the soil surface. A syringe-pump was then used to add distilled water at a rate of $0.2 \mathrm{ml} \mathrm{m^{-1 }}$ to the soil surface and the leachate collected from the base of the columns after the passage of $1,2,3,4$ and 5 pore volumes. The ${ }^{14} \mathrm{C}$ content of the leachate was determined as described above.

\subsection{Soil, biochar properties and biomass analysis}

The $\mathrm{pH}$ and electrical conductivity $(1: 5 \mathrm{w} / \mathrm{v}$ with distilled water for biochar and 1: $2.5 \mathrm{w} / \mathrm{v}$ for soil) of the biochar and soil were determined with standard electrodes. The WHC was measured using the international standard method, ISO16378 (Ref). Briefly, $2.0 \mathrm{~g}$ of biochar, soil or straw was saturated in distilled water for $4 \mathrm{~h}$, and then placed on moist sand for $2 \mathrm{~h}$. The sample was then oven-dried $\left(105^{\circ} \mathrm{C}, 24 \mathrm{~h}\right)$ to determine their water content. Available $\mathrm{NH}_{4}{ }^{+}$and $\mathrm{NO}_{3}{ }^{-}$ were determined in $0.5 \mathrm{M} \mathrm{K}_{2} \mathrm{SO}_{4}$ extracts (1:5 w/v) using the colorimetric methods of Mulvaney (1996) and Miranda et al. (2001), respectively. Available P was extracted from the soil and biochar using $0.5 \mathrm{M}$ acetic acid $(1: 5 \mathrm{w} / \mathrm{v})$ and $\mathrm{P}$ determined colorimetrically using the molybdate blue method of Murphy and Riley (1962). 


\section{7 $\quad$ Statistical analyses}

A Langmuir (Equation 2) or Freundlich (Equation 3) isotherm equation was fitted to the simazine adsorption data as shown below:

$$
\begin{aligned}
& \frac{C_{\mathrm{e}}}{q_{\mathrm{e}}}=\frac{1}{q_{\max } K_{\mathrm{L}}}+\frac{C_{\mathrm{e}}}{q_{\max }}, \\
& \ln q_{\mathrm{e}}=\ln K_{\mathrm{F}}+\frac{1}{n} \ln C_{\mathrm{e}},
\end{aligned}
$$

where $q_{\mathrm{e}}$ and $q_{\max }$ are the equilibrium and maximum adsorption capacities $\left(\mathrm{mg} \mathrm{g}^{-1}\right)$, respectively; $K_{\mathrm{L}}$, the Langmuir constant related to the affinity of the binding sites $\left(\mathrm{L} \mathrm{mg}^{-1}\right)$ and $C_{\mathrm{e}}$, the equilibrium concentration of adsorbate in an aqueous phases $\left(\mathrm{mg} \mathrm{L}^{-1}\right) . K_{\mathrm{F}}$ is a constant representing adsorption capacity, and $\mathrm{n}$ is a constant reflecting the adsorption intensity.

Statistical analyses were performed with software SPSS v26.0 (IBM Inc.). First, each variable was tested for normality with the Shapiro-Wilk's test and homogeneity of variance test with Levene's test. The variables which were not normally

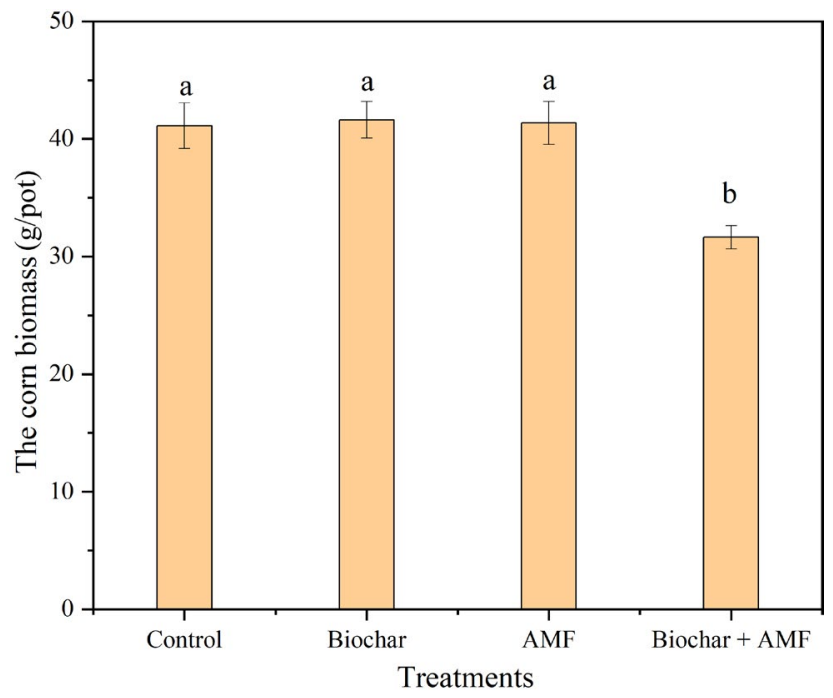

F I G U RE 2 Effects of arbuscular mycorrhizal fungi (AMF) and biochar amendments on maize biomass distributed or had unequal variances (such as decomposition and adsorption) were tested using a non-parametric Wilcoxon paired signed-rank test. The difference in biomass, simazine residues and leachates between the different treatments was analysed using a one-way ANOVA with Fisher's least significant difference (LSD), and paired sample t-tests. All the differences were considered significant at the $p<0.05$ level. The linear regression was undertaken in Origin 2019b (OriginLab Corp).

\section{3 | RESULTS}

\section{1 | Soil and biochar properties and maize yield}

The physical and chemical properties of the biochar and soil are listed in Table 1. Maize yields from the pot experiment are shown in Figure 2, and show no significant effect between the biochar and biochar + AMF treatments and the control. However, the maize yield from the AMF treatment was significantly lower than the yields in other treatments.

\section{2 | Simazine decomposition}

The decomposition rates of simazine are shown in Figure 3. At the end of the symbiosis experiment (in the presence of plants; Figure 3a), the cumulative decomposition of simazine in the biochar treatment was significantly lower (3\%) than that in the control. Compared to biochar treatment, AMF inoculation significantly increased $(0.5 \%)$ the decomposition of simazine. However, the cumulative decomposition of simazine in the AMF treatment was not significant different to the decomposition of simazine in the control, although at the mid-point of the pot experiment, the decomposition of simazine in the inoculated AMF treatment was faster than that of the control.

In the no symbiosis (absence of plants) incubation experiment (Figure 3b), AMF inoculation did not increase simazine decomposition, with the decomposition of simazine in the AMF treatment being significantly lower than in the control. Moreover, the ${ }^{14} \mathrm{C}$ activity in the plant and soil are shown in
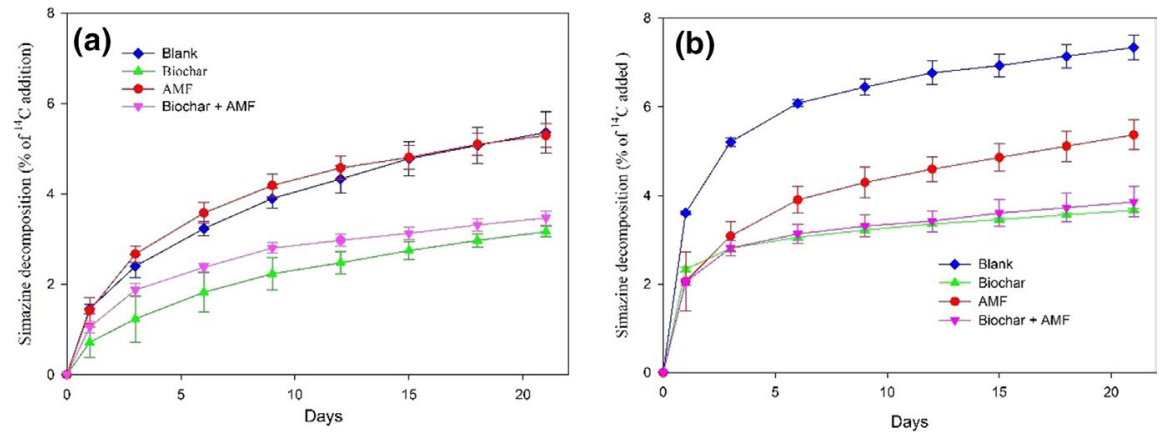

F I G URE 3 Cumulative decomposition rates of simazine (a) in the presence of plants; (b) in the absence of plants 


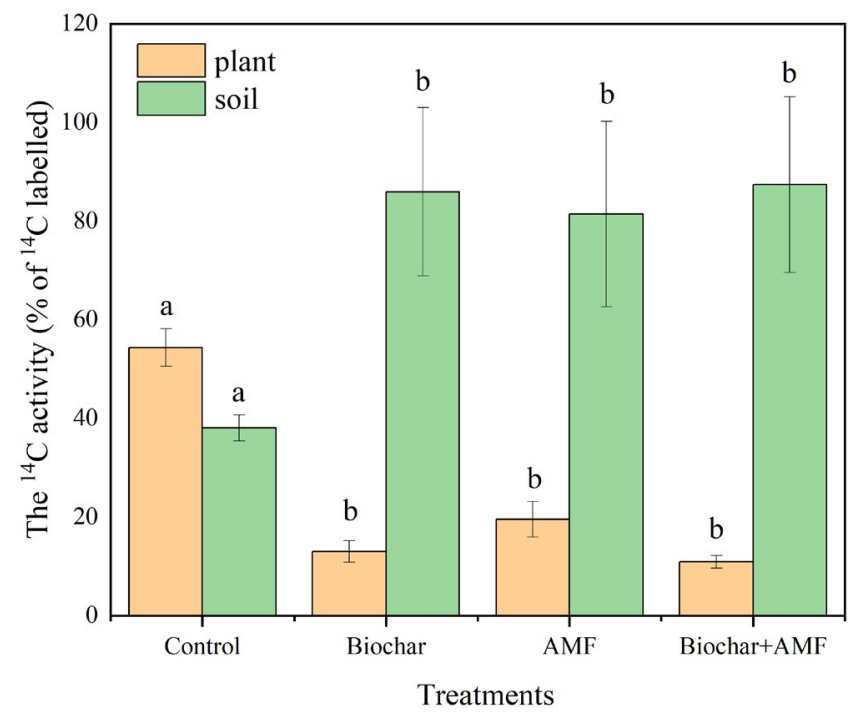

F I G U RE 4 Effect of arbuscular mycorrhizal fungi (AMF) and biochar amendments on ${ }^{14} \mathrm{C}$ activity in maize shoots and soil

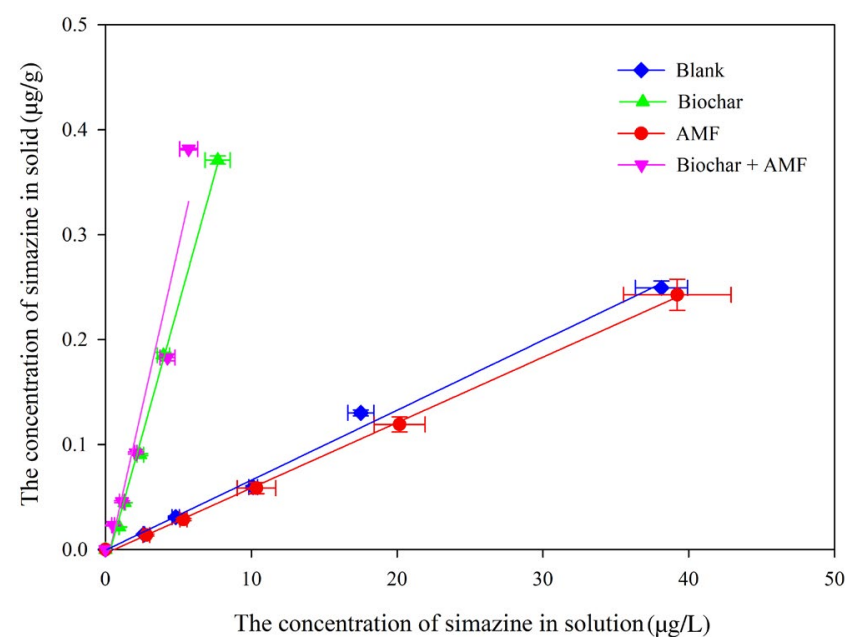

F I G URE 5 Effect of arbuscular mycorrhizal fungi (AMF) and biochar amendments on simazine sorption

Figure 4. The ${ }^{14} \mathrm{C}$ activity in plants which were collected from the biochar amended treatment and AMF inoculation treatment was low, whereas the ${ }^{14} \mathrm{C}$ activity in soil which were collected from biochar and AMF added treatments was high.

\section{3 | Simazine adsorption}

Adsorption isotherms of simazine for the biochar and AMF treatments were evaluated using the models of Langmuir and Freundlich. According to the $R^{2}$ values, it was clear that Freundlich equation better fitted to the experiment $\left(R^{2}>0.94\right)$. The $K_{\mathrm{d}}$ was significantly higher in the soil amended with biochar (Figure 5). The adsorption capacity constant $K_{\mathrm{f}}$ were $0.005,0.027,0.005$ and 0.043 , respectively, in the control, soil amended with biochar, soil inoculated

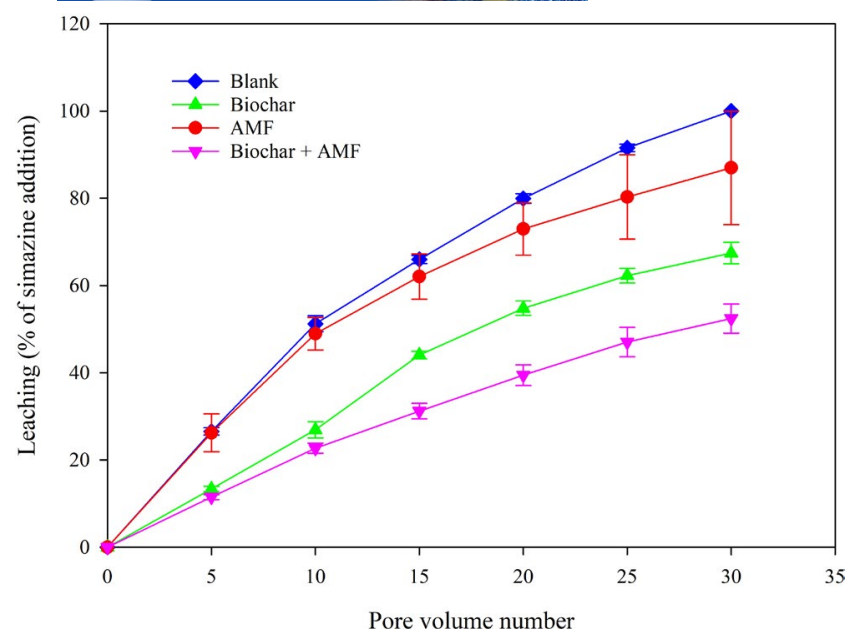

F I G U RE 6 Effect of arbuscular mycorrhizal fungi (AMF) and biochar amendments on simazine leaching

AMF, and soil amended with biochar inoculated AMF. Additionally, the adsorption intensity constant $n$ was 0.94 , $0.77,0.93$ and 0.94 , respectively, in the control, soil amended with biochar, soil inoculated AMF and soil amended with biochar inoculated AMF.

\section{4 | Simazine leaching}

The results of simazine leaching are shown in Figure 6. Biochar amendments significantly decreased simazine concentrations (by 32.5\%) in the leachate compared to control treatment. Moreover, the AMF inoculation also decreased the simazine concentration (13.0\%) in the leachate. The lowest concentration of simazine in the leachate, compared with the control (47.6\%), was observed in the AMF inoculation with biochar treatment $(p<0.05)$.

\section{4 | DISCUSSION}

\section{1 | Simazine behaviour in soil amended with biochar}

Due to their high specific area and micro-porous structures (Khorram et al., 2015; Srinivasan \& Sarmah, 2015), biochar is considered be a good sorbent, which results in the suppression of pesticide biodegradation (Jones et al., 2011; Yu et al., 2009) and also lower potential leaching of pesticides into groundwater (Marín-Benito et al., 2013). As seen previously (Cheng et al., 2017; Jones et al., 2011), in this study, biochar addition also significantly decreased the decomposition of simazine and decreased the simazine concentration in the leachate compared to an unamended soil. In addition, biochar application significantly decreased the ${ }^{14} \mathrm{C}$ activity in the plant and increased the 
TA B LE 2 Parameters of the simazine sorption isotherm for biochar using the Langmuir and Freundlich model

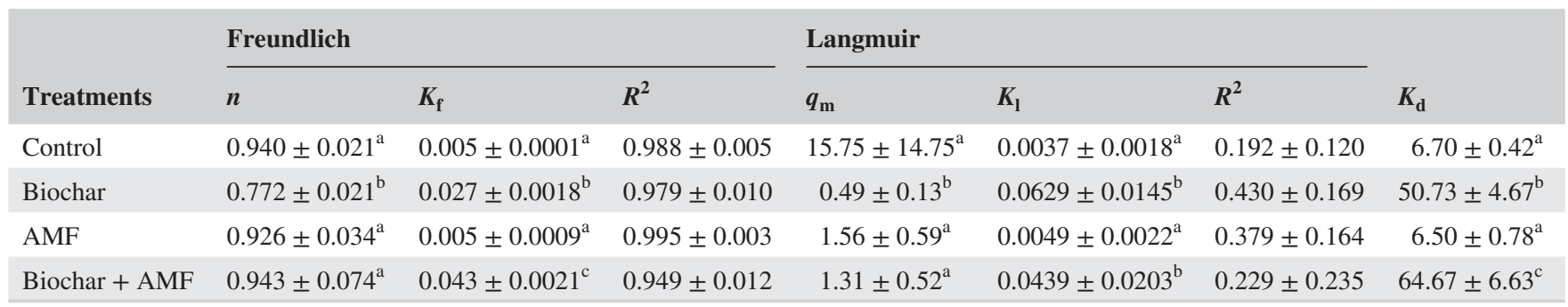

Note: All values represent means \pm SEM $(n=3)$. Different superscript letters represent significant differences between treatments at the $p<0.05$ level $(n$ represents ANOVA results and $K_{\mathrm{f}}$ represents non-parametric test: Mann-Whitney test results).

${ }^{14} \mathrm{C}$ activity in the soil (Figure 4). Two mechanisms are likely to explain these observations: (1) biochar altered the bioavailability of pesticides in soil (Jones et al., 2011). The adsorption results (Figure 5) indicated that biochar application increased the adsorption capacity of soil (Table 2), resulting in more simazine being retained in the soil and less simazine uptake by the crop. Although the ${ }^{14} \mathrm{C}$ activity (Figure 4) in the plant (or soil) was not equal to the simazine content in the plant (or soil), it indirectly showed that there is a less uptake of simazine by plant in the soil amended with biochar. The increased sorption by the biochar reduced the probability of simazine contacted with extracellular enzymes or microorganisms (Virchenko et al., 1986; Zhou et al., 2010), thus decreasing simazine biodegradation (Loganathan et al., 2009). (2) Biochar application modified the microbial community composition and activity (Lehmann et al., 2011) which subsequently affected the degradation of simazine. Biochar applications can result in increased soil $\mathrm{pH}$, the priming of carbon and addition of micro-porous structures that are all important factors in regulating microbial community composition, microbial biomass and activity (Lehmann et al., 2011). For example, Cheng et al. (2019) reported that biochar application significantly influenced soil bacterial community characteristics in karst soil by affecting soil physiochemical properties, suggesting that biochar addition affected microbial population abundance, community structure and enzyme activities. Overall, these results showed that biochar application has the potential to decrease simazine decomposition and reduce the risk of groundwater and surface water pollution (Ahmad et al., 2014).

\section{2 | The influence of AMF inoculation on the fate of simazine in soil}

Arbuscular mycorrhizal symbiosis is a key evolutionary strategy for enhancing nutrient capture by the associated host plant, while in return providing a supply of carbon to the fungus (Smith \& Read, 2008). Previous studies have demonstrated that a range of abiotic and biotic factors, including AM associations (Hodge \& Millard, 1998; Hodge et al., 2007; Jones et al., 2004, 2009; Paterson et al., 1999) influence soil OM decomposition and rhizodeposition processes
(Bird et al., 2011; Bottner et al., 1999; Dijkstra et al., 2009). In this study, AMF inoculated soil had no influence on simazine decomposition when the symbiosis had formed with the host plant (Figure 3a), whereas AMF inoculation decreased simazine decomposition in the absence of plants (Figure 3b). These results are in contrast with those reported previously, where arbuscular mycorrhizal symbiosis enhances OM mineralization (Hodge et al., 2007; Jones et al., 2004, 2009; Paterson et al., 1999). Because AMF has no saprotrophic capability, AMF inoculation results in the competition between AMF and other microbial decomposers for nutrition, which inhibited the development of other decomposing microorganisms (Hodge \& Millard, 1998). This could be the reason for the significant decrease in simazine decomposition in the AMF inoculation treatment without plants. The plant biomass in the different treatment (Figure 2) also confirmed that nutrient competition between AMF and plants or other microorganisms may exist. The decreased of simazine decomposition due to nutrient competition and the increased of simazine decomposition because of enhancement of carbon and nutrient circulation both worked simultaneously, resulted in no difference in simazine decomposition between the AMF inoculation treatment and the control when plants were present (Figure 3a). This interpretation is supported by the measured simazine degradation rates in the absence of plants where there was no AM symbiosis.

\subsection{The influence of AMF inoculation on the fate of simazine in soil amended with biochar}

When AM symbiosis existed, simazine decomposition was significantly increased in AMF inoculated soil amended with biochar, compared to the uninoculated AMF treatment (Figure 3a). Whereas, when there were no plants present, there was no difference in simazine degradation between the AMF + Biochar treatment and the biochar (only) treatment (Figure 3b). Compared to the control, biochar application directly supplies nutrients to the soil (Biederman \& Stanley Harpole, 2013), which mitigates the competition for nutrients between AMF and plants or other microbial decomposers, and 
increased simazine decomposition. The plant biomass results (Figure 2) also confirm that nutrient supplies was better in the biochar + AMF treatment than in the control. Therefore, AMF inoculation in the biochar amended soil alleviated the inhibiting effect of biochar on simazine decomposition. Furthermore, AMF inoculated into the biochar amended soil greatly increased the adsorption capacity of simazine (Table 2) compared to the biochar (only) application, with sorption capacity $K_{\mathrm{f}}$, increasing from 0.027 (in the biochar only) to 0.043 (in the AMF + Biochar). The increase in contact area between the simazine and solid interphases, provided by the AMF mycelium, was not sufficient to explain this.

\section{4 | Potential implications of combined $\mathrm{AMF}$ and biochar for controlling environmental contamination}

Recently, biochar and AMF amendments have reviewed increasing attention as technologies for mitigating heavy metal contamination in soil (Hu et al., 2013; Vejvodová et al., 2020). For biochar, this is because of its porous structure, large surface area and dominance of micropores (Ahmad et al., 2014; Cao \& Harris, 2010). For AMF, multiple studies have shown that AMF can immobilize and compartmentalize heavy metals in hyphal cells (Andrade et al., 2010; Göhre \& Paszkowski, 2006), or produce metal chelation of glomalin, or fungal polyphosphates and metallothioneins to bind the heavy metal (Kaldorf et al., 1999; Vodnik et al., 2008). However, despite this increased understanding of the individual effects of AMF and biochar, there have been few studies that have explored the interactive, and potential synergistic effects (Mickan et al., 2016). In this study, AMF inoculation of soil amended with biochar decreased simazine concentrations in leachates (Figure 6) mitigated the inhibition of biochar on simazine decomposition (Figure 3), and decreased pesticide uptake by plants (Figure 4). These results indicate the synergistic effect of combining AMF and biochar amendment could be exploited as a strategy to reduce diffuse losses of pesticides like simazine to surface waters and aquifers, with implications for the protection of human health. Moreover, AMF inoculation of biochar amended soil mitigated against pesticide accumulation that is often observed in biochar only amended soil, increasing pesticide degradation. Because there have been so few studies that have explored the synergistic effects of AMF inoculation of biochar amended soil, we propose that further research should explore the way in which combined AMF and biochar affect the biotic and abiotic processes that control the fate of pesticides.

\section{5 | CONCLUSION}

The application of biochar to agricultural soils has been shown to mitigate greenhouse gas emissions, improve soil quality and reduce the losses of contaminants, for example, heavy metals and pesticides, to water. The results presented here suggested that AMF inoculation to soil amended with biochar has the potential to significantly mitigate the negative influence of biochar (alone) on simazine decomposition. We conclude that AMF inoculation to biochar amended soil will decrease the potential contamination of surface and groundwaters with pesticides such as simazine, as well as reduce human exposure via potable water sources and direct crop uptake. Consequently, biochar application combined with AMF inoculation may make a valuable contribution to the development of sustainable agricultural systems. However, a more comprehensive understanding of factors that control the synergistic effects of AMF and biochar on the biotic and abiotic processes that control the fate of pesticides is needed.

\section{ACKNOWLEDGEMENTS}

This research was supported by the Strategic Priority Research Program of Chinese Academy of Sciences (No. XDB40020402), the National Key Research and Development Program of China (2018YFC1802601), National Natural Science Foundation of China (No. C200709), Opening Fund of the State Key Laboratory of Environmental Geochemistry (SKLEG 2020205) and Science and Technology Plan Project of Guizhou Province (No. [2018]2329).

\section{CONFLICT OF INTEREST}

The authors declare that they have no known competing financial interests or personal relationships that could have appeared to influence the work reported in this paper.

\section{AUTHOR CONTRIBUTIONS}

Hongguang Cheng was responsible for the manuscript writing and the experiment design, Dan Xing and Jinyang Wang analysed the data, Jinyang Wang and Shan Lin were responsible for the experimental work, and Chenglong Tu was responsible for the experimental design. Davey L. Jones, Dave Chadwick and Paul Hill were responsible for the overall planning of the experiment and the revision of the manuscript.

\section{DATA AVAILABILITY STATEMENT}

The data that support the findings of this study are available on request from the corresponding author. The data are not publicly available due to privacy or ethical restrictions.

\section{ORCID}

Hongguang Cheng (D) https://orcid.org/0000-0003-4731-7374 


\section{REFERENCES}

Ahmad, M., Rajapaksha, A. U., Lim, J. E., Zhang, M., Bolan, N., Mohan, D., Vithanage, M., Lee, S. S., \& Ok, Y. S. (2014). Biochar as a sorbent for contaminant management in soil and water: A review. Chemosphere, 99, 19-23. https://doi.org/10.1016/j.chemo sphere.2013.10.071

Andrade, S. A. L., Silveira, A. P. D., \& Mazzafera, P. (2010). Arbuscular mycorrhiza alters metal uptake and the physiological response of Coffea arabica seedlings to increasing $\mathrm{Zn}$ and $\mathrm{Cu}$ concentrations in soil. Science of the Total Environment, 408, 5381-5391. https:// doi.org/10.1016/j.scitotenv.2010.07.064

Atkinson, C. J., Fitzgerald, J. D., \& Hipps, N. A. (2010). Potential mechanisms for achieving agricultural benefits from biochar application to temperate soils: A review. Plant and Soil, 337, 1-18. https://doi. org/10.1007/s11104-010-0464-5

Bender, S. F., Plantenga, F., Neftel, A., Jocher, M., Oberholzer, H.-R., Köhl, L., Giles, M., Daniell, T. J., \& van der Heijden, M. G. (2014). Symbiotic relationships between soil fungi and plants reduce $\mathrm{N}_{2} \mathrm{O}$ emissions from soil. The ISME Journal, 8, 1336-1345. https://doi. org/10.1038/ismej.2013.224

Biederman, L. A., \& Stanley Harpole, W. (2013). Biochar and its effects on plant productivity and nutrient cycling: A meta-analysis. $G C B$ Bioenergy, 5, 202-214. https://doi.org/10.1111/gcbb.12037

Bird, J. A., Herman, D. J., \& Firestone, M. K. (2011). Rhizosphere priming of soil organic matter by bacterial groups in a grassland soil. Soil Biology and Biochemistry, 43, 718-725. https://doi.org/ 10.1016/j.soilbio.2010.08.010

Birnbaum, L. S., \& Fenton, S. E. (2003). Cancer and developmental exposure to endocrine disruptors. Environmental Health Perspectives, 111, 389-394. https://doi.org/10.1289/ehp.568

Bogdanffy, M. S., O’ Connor, J. C., Hansen, J. F., Gaddamidi, V., Van Pelt, C. S., Green, J. W., \& Cook, J. C. (2000). Chronic toxicity and oncogenicity bioassay in rats with the chloro-s-triazine herbicide cyanazine. Journal of Toxicology and Environmental Health - Part A, 60, 567-586. https://doi.org/10.1080/00984100050082102

Bottner, P., Sallih, Z., \& Pansu, M. (1999). Modelling the effect of active roots on soil organic matter turnover. Plant and Soil, 216, 15-25. https://doi.org/10.1023/A:1004769317657

Camps Arbestain, M., Saggar, S., \& Leifeld, J. (2014). Environmental benefits and risks of biochar application to soil. Agriculture, Ecosystems \& Environment, 191, 1-4. https://doi.org/10.1016/j.agee.2014. 04.014

Cao, X., \& Harris, W. (2010). Properties of dairy-manure-derived biochar pertinent to its potential use in remediation. Bioresource Technology, 101, 5222-5228. https://doi.org/10.1016/j.biortech. 2010.02.052

Chang, J., Clay, D. E., Clay, S. A., Chintala, R., Miller, J. M., \& Schumacher, T. (2016). Biochar reduced nitrous oxide and carbon dioxide emissions from soil with different water and temperature cycles. Agronomy Journal, 108, 2214-2221. https://doi. org/10.2134/agronj2016.02.0100

Cheng, L., Booker, F. L., Tu, C., Burkey, K. O., Zhou, L., Shew, H. D., Rufty, T. W., \& Hu, S. (2012). Arbuscular mycorrhizal fungi increase organic carbon decomposition under elevated $\mathrm{CO}_{2}$. Science, 337, 1084-1087. https://doi.org/10.1126/science.1224304

Cheng, H., Jones, D. L., Hill, P., \& Bastami, M. S. (2017). Biochar concomitantly increases simazine sorption in sandy loam soil and lowers its dissipation. Archives of Agronomy and Soil Science, 63, 1082-1092. https://doi.org/10.1080/03650340.2016.1261117
Cheng, J., Lee, X., Tang, Y., \& Zhang, Q. (2019). Long-term effects of biochar amendment on rhizosphere and bulk soil microbial communities in a karst region, southwest China. Applied Soil Ecology, 140, 126-134.

Cox, L., Celis, R., Hermosín, M. C., \& Cornejo, J. (2000). Natural soil colloids to retard simazine and 2,4-D leaching in soil. Journal of Agricultural and Food Chemistry, 48, 93-99. https://doi. org/10.1021/jf990585k

Dijkstra, F. A., Bader, N. E., Johnson, D. W., \& Cheng, W. (2009). Does accelerated soil organic matter decomposition in the presence of plants increase plant N availability? Soil Biology and Biochemistry, 41, 1080-1087. https://doi.org/10.1016/j.soilbio.2009.02.013

Eibisch, N., Schroll, R., Fuß, R., Mikutta, R., Helfrich, M., \& Flessa, H. (2015). Pyrochars and hydrochars differently alter the sorption of the herbicide isoproturon in an agricultural soil. Chemosphere, 119, 155-162. https://doi.org/10.1016/j.chemosphere.2014.05.059

Farrar, J., Boddy, E., Hill, P. W., \& Jones, D. L. (2012). Discrete functional pools of soil organic matter in a UK grassland soil are differentially affected by temperature and priming. Soil Biology and Biochemistry, 49, 52-60. https://doi.org/10.1016/j.soilbio. 2012.02.018

Göhre, V., \& Paszkowski, U. (2006). Contribution of the arbuscular mycorrhizal symbiosis to heavy metal phytoremediation. Planta, 223, 1115-1122. https://doi.org/10.1007/s00425-006-0225-0

Graber, E. R., Tsechansky, L., Gerstl, Z., \& Lew, B. (2012). High surface area biochar negatively impacts herbicide efficacy. Plant and Soil, 353, 95-106. https://doi.org/10.1007/s11104-011-1012-7

Gui, H., Hyde, K., Xu, J., \& Mortimer, P. (2017). Arbuscular mycorrhiza enhance the rate of litter decomposition while inhibiting soil microbial community development. Scientific Reports, 7, 1-11. https://doi.org/10.1038/srep42184

Hayes, T. B., Case, P., Chui, S., Chung, D., Haeffele, C., Haston, K., Lee, M., Mai, V. P., Marjuoa, Y., Parker, J., \& Tsui, M. (2006). Pesticide mixtures, endocrine disruption, and amphibian declines: Are we underestimating the impact? Environmental Health Perspectives, 114, 40-50. https://doi.org/10.1289/ehp.8051

Herman,D.J.,Firestone,M.K.,Nuccio,E.,\&Hodge,A.(2012).Interactions between an arbuscular mycorrhizal fungus and a soil microbial community mediating litter decomposition. FEMS Microbiology Ecology, 80(1), 236-247. https://doi.org/10.1111/j.1574-6941. 2011.01292.x

Hoagland and Arnon. (1950). The water-culture method for growing plants without soil. University of California, College of Agriculture, Agricultural Experiment Station.

Hodge, A., Campbell, C. D., \& Fitter, A. H. (2001). An arbuscular mycorrhizal fungus accelerates decomposition and achqires nitrogen directly from organic material. Nature, 413, 297-299. https://doi. org/10.1038/35095041

Hodge, A., \& Millard, P. (1998). Effect of elevated $\mathrm{CO}_{2}$ on carbon partitioning and exudate release from Plantago lanceolata seedlings. Physiologia Plantarum, https://doi.org/10.1034/j.1399-3054.1998. 1030216.x

Hodge, A., Paterson, E., Thornton, B., Millard, P., \& Killham, K. (2007). Effects of photon flux density on carbon partitioning and rhizosphere carbon flow of Lolium perenne. Journal of Experimental Botany, 48, 1797-1805. https://doi.org/10.1093/ $\mathrm{jxb} / 48.10 .1797$

Hu, J., Wu, S., Wu, F., Leung, H. M., Lin, X., \& Wong, M. H. (2013). Arbuscular mycorrhizal fungi enhance both absorption and stabilization of Cd by Alfred stonecrop (Sedum alfredii Hance) and 
perennial ryegrass (Lolium perenne $\mathrm{L}$.) in a Cd-contaminated acidic soil. Chemosphere, 93, 1359-1365. https://doi.org/10.1016/j.chemo sphere.2013.07.089

Ippolito, J. A., Laird, D. A., \& Busscher, W. J. (2012). Environmental benefits of biochar. Journal of Environment Quality, 41(4), 967972. https://doi.org/10.2134/jeq2012.0151

Jiang, L., Dami, I., Mathers, H. M., Dick, W. A., \& Doohan, D. (2011). The effect of straw mulch on simulated simazine leaching and runoff. Weed Science, 59, 580-586. https://doi.org/10.1614/ws-d-10-00103.1

Jones, D. L., Edwards-Jones, G., \& Murphy, D. V. (2011). Biochar mediated alterations in herbicide breakdown and leaching in soil. Soil Biology and Biochemistry, 43, 804-813. https://doi.org/10.1016/ J.SOILBIO.2010.12.015

Jones, D. L., Hodge, A., \& Kuzyakov, Y. (2004). Plant and mycorrhizal regulation of rhizodeposition. New Phytologist, 163, 459-480. https://doi.org/10.1111/j.1469-8137.2004.01130.x

Jones, D. L., Nguyen, C., \& Finlay, R. D. (2009). Carbon flow in the rhizosphere: Carbon trading at the soil-root interface. Plant and Soil, 321, 5-33. https://doi.org/10.1007/s11104-009-9925-0

Jones, D. L., Rousk, J., Edwards-Jones, G., DeLuca, T. H., \& Murphy, D. V. (2012). Biochar-mediated changes in soil quality and plant growth in a three year field trial. Soil Biology and Biochemistry, 45, 113-124. https://doi.org/10.1016/J.SOILBIO.2011.10.012

Kaldorf, M., Kuhn, A. J., Schröder, W. H., Hildebrandt, U., \& Bothe, H. (1999). Selective element deposits in maize colonized by a heavy metal tolerance conferring arbuscular mycorrhizal fungus. Journal of Plant Physiology, 154, 718-728. https://doi.org/10.1016/S01761617(99)80250-8

Khorram, M. S., Wang, Y., Jin, X., Fang, H., \& Yu, Y. (2015). Reduced mobility of fomesafen through enhanced adsorption in biocharamended soil. Environmental Toxicology and Chemistry, 34, 1258-1266. https://doi.org/10.1002/etc.2946

Koller, R., Rodriguez, A., Robin, C., Scheu, S., \& Bonkowski, M. (2013). Protozoa enhance foraging efficiency of arbuscular mycorrhizal fungi for mineral nitrogen from organic matter in soil to the benefit of host plants. New Phytologist, 199, 203-211. https:// doi.org/10.1111/nph.12249

Kookana, R. S. (2010). The role of biochar in modifying the environmental fate, bioavailability, and efficacy of pesticides in soils: A review. Australian Journal of Soil Research, 48, 627-637. https:// doi.org/10.1071/SR10007

Kookana, R. S., Sarmah, A. K., Van Zwieten, L., Krull, E., \& Singh, B. (2011). Biochar application to soil. agronomic and environmental benefits and unintended consequences, 1st ed, advances in agronomy. Elsevier Inc. https://doi.org/10.1016/B978-0-12-38553 8-1.00003-2

Kookana, R. S., Schuller, R. D., \& Aylmore, L. A. G. (1993). Simulation of simazine transport through soil columns using time-dependent sorption data measured under flow conditions. Journal of Contaminant Hydrology, 14, 93-115. https://doi.org/10.1016/ 0169-7722(93)90033-O

Kuppusamy, S., Thavamani, P., Megharaj, M., Venkateswarlu, K., \& Naidu, R. (2016). Agronomic and remedial benefits and risks of applying biochar to soil: Current knowledge and future research directions. Environment International, 87, 1-12. https://doi. org/10.1016/j.envint.2015.10.018

Kuzyakov, Y., \& Jones, D. L. (2006). Glucose uptake by maize roots and its transformation in the rhizosphere. Soil Biology and Biochemistry, 38, 851-860. https://doi.org/10.1016/j.soilbio. 2005.07.012
Larsbo, M., Löfstrand, E., De Veer, D. V. A., \& Ulén, B. (2013). Pesticide leaching from two Swedish topsoils of contrasting texture amended with biochar. Journal of Contaminant Hydrology, 147, 73-81. https://doi.org/10.1016/j.jconhyd.2013.01.003

Lehmann, J., \& Joseph, S. (2009). Biochar for environmental management: Science and technology. https://doi.org/10.1016/j.forpol. 2009.07.001

Lehmann, J., Rillig, M. C., Thies, J., Masiello, C. A., Hockaday, W. C., \& Crowley, D. (2011). Biochar effects on soil biota - A review. Soil Biology and Biochemistry, 43(9), 1812-1836. https:// doi.org/10.1016/j.soilbio.2011.04.022

Loganathan, V. A., Feng, Y., Sheng, G. D., \& Clement, T. P. (2009). Crop-residue-derived char influences sorption, desorption and bioavailability of atrazine in soils. Soil Science Society of America Journal, 73, 967-974. https://doi.org/10.2136/sssaj2008.0208

Mandal, S., Sarkar, B., Bolan, N., Ok, Y. S., \& Naidu, R. (2017). Enhancement of chromate reduction in soils by surface modified biochar. Journal of Environmental Management, 186, 277-284. https://doi.org/10.1016/j.jenvman.2016.05.034

Maraseni, T. N. (2010). Biochar: Maximising the benefits. International Journal of Environmental Studies., 67(3), 319-327. https://doi. org/10.1080/00207231003612225

Marín-Benito, J. M., Brown, C. D., Herrero-Hernández, E., Arienzo, M., Sánchez-Martín, M. J., \& Rodríguez-Cruz, M. S. (2013). Use of raw or incubated organic wastes as amendments in reducing pesticide leaching through soil columns. Science of the Total Environment, 463-464, 589-599. https://doi.org/10.1016/j.scitotenv. 2013.06.051

Mickan, B. S., Abbott, L. K., Stefanova, K., \& Solaiman, Z. M. (2016). Interactions between biochar and mycorrhizal fungi in a waterstressed agricultural soil. Mycorrhiza, 26, 565-574. https://doi. org/10.1007/s00572-016-0693-4

Miranda, K. M., Espey, M. G., \& Wink, D. A. (2001). A rapid, simple spectrophotometric method for simultaneous detection of nitrate and nitrite. Nitric Oxide, 5, 62-71. https://doi.org/10.1006/niox. 2000.0319

Mulvaney, R. (1996). Nitrogen-inorganic forms. In D. L. Sparks (Ed.), Methods of soil analysis. Part 3. Chemical methods (pp. 11231184). SSSA.

Murphy, J., \& Riley, J. P. (1962). A modified single solution method for the determination of phosphate in natural waters. Analytica Chimica Acta, 27, 31-36.

Nag, S. K., Kookana, R., Smith, L., Krull, E., Macdonald, L. M., \& Gill, G. (2011). Poor efficacy of herbicides in biochar-amended soils as affected by their chemistry and mode of action. Chemosphere, 84, 1572-1577. https://doi.org/10.1016/j.chemosphere. 2011.05.052

Paterson, E., Hodge, A., Thornton, B., Millard, P., \& Killham, K. (1999). Carbon partitioning and rhizosphere $\mathrm{C}$-flow in Lolium perenne as affected by $\mathrm{CO}_{2}$ concentration, irradiance and below-ground conditions. Global Change Biology, 5, 669-678. https://doi. org/10.1046/j.1365-2486.1999.00267.x

Rico, A., Satapornvanit, K., Haque, M. M., Min, J., Nguyen, P. T., Telfer, T. C., \& van den Brink, P. J. (2012). Use of chemicals and biological products in Asian aquaculture and their potential environmental risks: A critical review. Reviews in Aquaculture, 4, 75-93. https://doi.org/10.1111/j.1753-5131.2012.01062.x

Safaei Khorram, M., Fatemi, A., Khan, M. A., Kiefer, R., \& Jafarnia, S. (2018). Potential risk of weed outbreak by increasing biochar's application rates in slow-growth legume, lentil (Lens culinaris 
Medik.). Journal of the Science of Food and Agriculture, 98, 2080-2088. https://doi.org/10.1002/jsfa.8689

Smith, S., \& Read, D. (2008). Mycorrhizal symbiosis, mycorrhizal symbiosis. Elsevier Ltd. https://doi.org/10.1016/B978-0-12-370526-6. X5001-6

Spokas, K. A., Cantrell, K. B., Novak, J. M., Archer, D. W., Ippolito, J. A., Collins, H. P., Boateng, A. A., Lima, I. M., Lamb, M. C., McAloon, A. J., Lentz, R. D., \& Nichols, K. A. (2012). Biochar: A synthesis of its agronomic impact beyond carbon sequestration. Journal of Environment Quality, 41, 973-989. https://doi.org/ 10.2134/jeq2011.0069

Srinivasan, P., \& Sarmah, A. K. (2015). Characterisation of agricultural waste-derived biochars and their sorption potential for sulfamethoxazole in pasture soil: A spectroscopic investigation. Science of the Total Environment, 502, 471-480. https://doi.org/10.1016/ j.scitotenv.2014.09.048

Tatarková, V., Hiller, E., \& Vaculík, M. (2013). Impact of wheat straw biochar addition to soil on the sorption, leaching, dissipation of the herbicide (4-chloro-2-methylphenoxy)acetic acid and the growth of sunflower (Helianthus annuus L.). Ecotoxicology and Environmental Safety, 92, 215-221. https://doi.org/10.1016/ j.ecoenv.2013.02.005

Trakal, L., Veselská, V., Šafařík, I., Vítková, M., Č́íhalová, S., \& Komárek, M. (2016). Lead and cadmium sorption mechanisms on magnetically modified biochars. Bioresource Technology, 203, 318-324. https://doi.org/10.1016/J.BIORTECH.2015.12.056

Troiano, J., Weaver, D., Marade, J., Spurlock, F., Pepple, M., Nordmark, C., \& Bartkowiak, D. (2001). Summary of well water sampling in California to detect pesticide residues resulting from nonpoint-source applications. Journal of Environmental Quality, 30, 448-459. https://doi.org/10.2134/jeq2001.302448x

Vejvodová, K., Száková, J., García-Sánchez, M., Praus, L., Romera, I. G., \& Tlustoš, P. (2020). Effect of dry olive residue-based biochar and arbuscular mycorrhizal fungi inoculation on the nutrient status and trace element contents in wheat grown in the As-, Cd-, $\mathrm{Pb}-$, and $\mathrm{Zn}$-contaminated soils. Journal of Soil Science and Plant Nutrition, 20(3), 1067-1079. https://doi.org/10.1007/s42729-02000193-2

Virchenko, S. B., Povzhitkova, M. S., Lysenko, M. K., \& Kozhekova, T. N. (1986). Adsorption of gastric juice pepsin by activated charcoal. Fiziologicheskii Zhurnal, 32, 293-297.

Vodnik, D., Grčman, H., Maček, I., van Elteren, J. T., \& Kovačevič, M. (2008). The contribution of glomalin-related soil protein to $\mathrm{Pb}$ and
$\mathrm{Zn}$ sequestration in polluted soil. Science of the Total Environment, 392, 130-136. https://doi.org/10.1016/j.scitotenv.2007.11.016

Wauchope, R. D., Buttler, T. M., Hornsby, A. G., Augustijn-Beckers, P. W. M., \& Burt, J. P. (1992). The SCS/ARS/CES pesticide properties database for environmental decision-making, 123, 1-155. https://doi.org/10.1007/978-1-4612-2862-2_1

Williams, M., Martin, S., \& Kookana, R. S. (2015). Sorption and plant uptake of pharmaceuticals from an artificially contaminated soil amended with biochars. Plant and Soil, 395(1-2), 75-86. https:// doi.org/10.1007/s11104-015-2421-9

Yang, X. B., Ying, G. G., Peng, P. A., Wang, L., Zhao, J. L., Zhang, L. J., Yuan, P., \& He, H. P. (2010). Influence of biochars on plant uptake and dissipation of two pesticides in an agricultural soil. Journal of Agricultural and Food Chemistry, 58, 7915-7921. https://doi. org/10.1021/jf1011352

Yang, Y., Sheng, G., \& Huang, M. (2006). Bioavailability of diuron in soil containing wheat-straw-derived char. Science of the Total Environment, 354(2-3), 170-178. https://doi.org/10.1016/j.scito tenv.2005.01.026

Yu, X. Y., Mu, C. L., Gu, C., Liu, C., \& Liu, X. J. (2011). Impact of woodchip biochar amendment on the sorption and dissipation of pesticide acetamiprid in agricultural soils. Chemosphere, 85, 1284-1289. https://doi.org/10.1016/j.chemosphere.2011.07.031

Yu, X., Pan, L., Ying, G., \& Kookana, R. S. (2010). Enhanced and irreversible sorption of pesticide pyrimethanil by soil amended with biochars. Journal of Environmental Sciences, 22, 615-620. https:// doi.org/10.1016/S1001-0742(09)60153-4

Yu, X. Y., Ying, G. G., \& Kookana, R. S. (2009). Reduced plant uptake of pesticides with biochar additions to soil. Chemosphere, 76, 665-671. https://doi.org/10.1016/j.chemosphere.2009.04.001

Zhou, Z., Shi, D., Qiu, Y., \& Sheng, G. D. (2010). Sorptive domains of pine chars as probed by benzene and nitrobenzene. Environmental Pollution, 158, 201-206. https://doi.org/10.1016/ j.envpol.2009.07.020

How to cite this article: Cheng $\mathrm{H}$, Wang J, Tu C, et al. Arbuscular mycorrhizal fungi and biochar influence simazine decomposition and leaching. $G C B$ Bioenergy. 2021;13:708-718. https://doi.org/10.1111/ gcbb. 12802 